\title{
Gerakan Literasi Sekolah (GLS) di Sekolah Dasar Unggulan Aisyiyah Taman Harapan Curup
}

\author{
Ummul Khair, Siti Partimah Fakar \\ Institut Agama Islam Negeri (IAIN) Curup \\ Email. Ummulkhair1213@gmail.com
}

\begin{abstract}
This research was conducted to determine the policy of school literacy movement in excellent primary school Aisyiyah Taman Harapan Curup. This research with the theory implementation Eward III namely: communication, resources, commitment, and bureaucracy structure and will describe the supporting and inhibiting factors in implementation the policy of school literacy movement. This research is a descriptive qualitative research which was carried out in a excellent primary school Aisyiyah Taman Harapan Curup in April-Juli 2018. The research subject were vice principal, head of library, and the fourth grade homeroom teacher. Technique collecting data is interview, observation, and documentation. The result of this research are as follows: (1) The policy implementation supported by: (a) implementing agencies communicate through meeting of school element such as management, parents, and teacher. (b) The resources that support this activity such as the potential of teacher funds from parent of the students as soon as goverment and sponsor. (c) commitment from implementing agencies. (d) Bureaucracy structure from part of school. (2) supporting factors in the form of the availability of means to socialize policies, book grant from parents, time and funds, teacher have a passion for learning, while the inhibiting factor teacher must be still reminded related to the policy Standard Operational Procedure and the program that still need to be done each other busy of ustadzah and ustadz which usually make the literacy process in the library and making wall magazine whic sudden because of limited human resources too. Parent often ignore incoming message via whatsapp need for program development so that it is not monotonous and students become bored.
\end{abstract}

Keyword: School Literacy Movement, SDUA THC.

\begin{abstract}
Abstrak
Penelitian ini dilakukan untuk mengetahui kebijakan gerakan literasi sekolah di Sekolah Dasar Unggulan Aisyiyah Taman Harapan Curup, penelitian ini dengan teori implementasi Edward III yaitu komunikasi, sumber daya, komitmen, dan struktur birokrasi, serta akan mendeskripsikan faktor pendukung dan penghambat dalam implementasi kebijakan gerakan literasi sekolah. Penelitian ini adalah penelitian deskriptif kualitatif, yang dilakukan di Sekolah Dasar Unggulan Aisyiyah Taman Harapan Curup, pada bulan April-Juli 2018. Subjek penelitian ialah wakil Kepala Sekolah, Kepala Perpustakaan, dan wali kelas IV. Teknik pengumpulan data yang digunakan ialah wawancara, observasi dan dokumentasi. Hasil penelitian ialah sebagai berikut: (1) implementasi kebijakan ini didukung oleh a). Komunikasi agen-agen pelaksana melalui rapat elemen sekolah seperti manajemen, orangtua, dan guru; b). Sumber daya yang
\end{abstract}


mendukung kegiatan ini seperti adanya potensi guru, dana dari orang tua siswa, sekolah, dan pemerintah serta sponsor; c). Komitmen dari para agen pelaksana; d). Struktur birokrasi baik dari pihak sekolah; (2). Faktor pendukung berupa tersedianya sarana untuk mensosialisasikan kebijakan, hibah buku dari orangtua, waktu dan dana, guru-guru mempunyai semangat belajar, Sedangkan faktor penghambatnya guru masih harus diingatkan terkait Standart Operational Procedure kebijakan dan program yang harus dilakukan, Kesibukkan masing-masing ustazah dan ustad yang biasanya menjadikan proses literasi di perpustakaan dan pembuatan mading yang mendadak karena keterbatasan sumber daya manusia juga. Orang tua sering mengabaikan pesan masuk melalui whatshapp, perlu adanya pengembangan program agar tidak monoton dan terjadi kebosanan siswa.

Kata kunci: Gerakan Literasi Sekolah, SDUA THC

\section{Pendahuluan}

Pendidikan adalah proses pengubahan sikap dan tata laku seseorang atau kelompok orang dalam usaha mendewasakan manusia melalui upaya pengajaran dan pelatihan, proses, cara, perbuatan mendidik. (KBBI; 2008.h. 263). Pendidikan merupakan instrumen yang paling penting sekaligus paling strategis untuk mencapai tujuan individual maupun sosial. Jika seseorang individu membangun mimpi-mimpi masa depan yang indah dan menjanjikan dalam kehidupannya, maka ia membutuhkan alat bantu untuk mewujudkannya. Mungkin saja ia bisa belajar dari lingkungan, teman, atau dari membaca buku. Semua itu merupakan jalan yang membuka kearah perwujudan mimpi. Tetapi dari semua mekanisme tersebut, pendidikan lewat jenjang sekolah yang paling memungkinkan dan memberi peluang besar untuk mencapainya. (Nagainum Naim; 2019,h.11).

Adapun pengertian pendidikan yang terdapat pada UU No. 20 tahun 2003, Bab 1 pasal 1 tentang sistem pendidikan (SISDIKNAS) adalah sebagai berikut:

Terkait dengan buku sebagai salah satu sumber informasi, rendahnya minat dan gairah membaca sebagian berakar dari masih kuatnya tradisi lisan dalam kehidupan sosial dan pola berpikir masyarakat Indonesia.

Gerakan Literasi Sekolah dikembangkan berdasarkan 9 agenda prioritas (Nawacita) yang terkait dengan tugas dan fungsi Kemendikbud, khususnya Nawacita nomor 5, 6, 8 dan 9. Empat butir Nawacita tersebut terkait erat dengan komponen literasi sebagai modal pembentukan sumber daya manusia yang berkualitas, produktif, dan berdaya saing, berkarakter, serta nasionalis. Salah satu kegiatan di dalam Gerakan Literasi Sekolah tersebut adalah kegiatan 15 menit membaca buku non pelajaran sebelum waktu belajar dimulai. Kegiatan ini dilaksanakan untuk menumbuhkan minat baca peserta didik serta meningkatkan keterampilan membaca agar pengetahuan dapat dikuasai secara lebih baik. Materi baca berisi nilai-nilai budi pekerti, berupa kearifan lokal, nasional, dan global yang disampaikan sesuai tahap perkembangan peserta didik. Terobosan penting ini hendaknya melibatkan semua pemangku kepentingan di bidang pendidikan, mulai dari tingkat pusat, provinsi, kabupaten/kota, hingga satuan pendidikan yaitu sekolah. Pelibatan orang tua peserta didik dan masyarakat juga menjadi komponen penting dalam keberhasilan Gerakan Literasi Sekolah. 
Sekolah Dasar Unggulan Aisyiah Taman Harapan Curup merupakan sekolah dasar yang memiliki misi meningkatkan mutu stakeholder sekolah dan penggunaan IPTEK dalam kegiatan belajar mengajar. Hal ini dapat diwujudkan apabila kegiatan pembelajaran di sekolah sudah mendukung untuk terbentuknya siswa yang memiliki wawasan yang luas dan mempunyai cara pandangan internasional. Salah satunya dengan membudayakan kegiatan literasi di sekolah. Di Sekolah Dasar Unggulan Aisyiyah sudah membiasakan budaya literasi di sekolah dengan adanya kegiatan literasi serta adanya perpustakaan mini di setiap kelas yang dibuat agar siswa dapat dengan mudah mengakses sumber literasi yang menunjang kebutuhan setiap siswa untuk berwawasan luas. Hal ini dilaksanakan semenjak keluar kebijakan mengenai gerakan literasi sekolah.

Bentuk penerapan Gerakan Literasi Sekolah yang terdapat di Sekolah Dasar Unggulan Sekolah Aisyiah yaitu kegiatan literasi yang berlangsung di luar dan di dalam kelas selama 15 menit. Kegiatan ini dilakukan setelah siswa melaksanakan kegiatan iqra. Siswa memilih salah satu buku yang berada di perpustakaan mini untuk dibaca, yang kemudian ditulis kembali dengan bahasa sendiri dibuku tulisnya. Kegiatan ini telah menjadi kegiatan rutin setiap harinya dan merupa kan kegiatan yang harus dilakukan oleh para siswa. Setiap siswa akan dinilai dalam pelaksanaan kegiatan ini dan masuk kedalam penilaian bahasa indonesia.

Selain itu sekolah juga menyediakan berbagai fasilitas yang menunjang kegiatan literasi seperti perpustakaan, green house, dan pojok baca. Fasilitas-fasilitas ini disediakan adalah upaya untuk mencapai tujuan dari kegiatan literasi.

Hal tersebut menunjukkan bahwa Sekolah Dasar Unggulan Aisyiyah telah mengimplementasikan Gerakan Literasi Sekolah sebagai upaya untuk meningkatkan budaya literasi pada siswa. Oleh karena itu, peneliti tertarik untuk mengkaji lebih dalam mengenai "Implementasi Kebijakan Gerakan Literasi Sekolah di Sekolah Dasar Unggulan Aisyiah Taman Harapan Curup" untuk mendeskripsikan implementasi kebijakan tersebut dan mengetahui faktor yang mendukung serta menghambat terlaksananya program serta melihat perkembangannya setelah diimplementasikan kebijakan tersebut. Penelitian ini juga dapat menjadi rekomendasi khususnya pada kebijakan Gerakan Literasi Sekolah itu sendiri.

\section{Landasan Teori}

\section{a. Landasan Filosofi}

Sumpah Pemuda butir ketiga (3) menyatakan, "menjunjung bahasa persatuan bahasa Indonesia yang memiliki makna pengakuan terhadap keberadaan ratusan bahasa daerah yang memiliki hak hidup dan peluang penggunaan bahasa asing sesuai dengan keperluannya."

1) Butir ini menegaskan pentingnya pembelajaran berbahasa dalam Pendidikan nasional.

2) Konvensi $\mathrm{PBB}$ tentang $\mathrm{Hak}$ Anak pada tahun 1989 tentang pentingnya penggunaan bahasa ibu. Indonesia yang memiliki beragam suku bangsa, khususnya mikrokultur-mikrokultur tertentu perlu difasilitasi dengan bahasa ibu saat mereka memasuki pendidikan dasar kelas rendah (kelas I, II, III). 
3) Konvensi PBB di Praha tahun 2003 tentang kecakapan literasi dasar dan kecakapan perpustakaan yang efektif merupakan kunci bagi masyarakat yang literat dalam menghadapi derasnya arus informasi teknologi. Lima komponen yang esensial dari literasi informasi itu adalah basic literacy, library literacy, media literacy, technology literacy, dan visual literacy. (Pangesti Wiedarti, 2016. h 4)

Dapat disimpulkan bahwa yang menjadi landasan filosofi pemerintah mengadakan program Gerakan Literasi Sekolah adalah Indonesia yang memiliki beragaman bahasa harus disatukan dengan bahasa pemersatu yaitu bahasa Indonesia. Setiap anak memiliki haknya untuk menggunakan bahasa ibu, hal ini bisa dilakukan ketika anak memasuki pendidikan sekolah tingkat rendah, dari kelas 1 sampai 3. Kecakapan literasi atau berbahasa sangat berguna, terlebih dengan arus informasi teknologi seperti saat ini.

\section{a. Landasan Hukum}

1) Undang-Undang Dasar 1945, Pasal 31, Ayat 3: "Pemerintah mengusahakan dan menyelenggarakan satu sistem pendidikan nasional yang meningkatkan keimanan dan ketakwaan serta akhlak mulia dalam rangka mencerdaskan kehidupan bangsa, yang diatur dengan undang-undang."

2) Undang-Undang Republik Indonesia Nomor 20 Tahun 2003 tentang Sistem Pendidikan Nasional.

3) Undang-Undang Republik Indonesia Nomor 43 Tahun 2007 pasal 4 Tentang Perpustakaan: "Keberadaan perpustakaan bertujuan untuk meningkatkan kegemaran membaca, serta memperluas wawasan dan pengetahuan untuk mencerdaskan kehidupan bangsa."

4) Undang-Undang Republik Indonesia Nomor 24 tahun 2009 tentang Bendera, Bahasa, dan Lambang Negara serta Lagu Kebangsaan.

5) Peraturan Pemerintah Republik Indonesia Nomor 32 Tahun 2013 tentang Perubahan Kedua atas Peraturan Pemerintah Republik Indonesia Nomor 19 tahun 2005 tentang Standar Nasional Pendidikan.

6) Peraturan Pemerintah Nomor 24 tahun 2014 tentang Pelaksanaan UU Nomor 43 Tahun 2007 tentang Perpustakaan.Peraturan Menteri Dalam Negeri Nomor 40 Tahun 2007 tentang

7) Pedoman bagi Kepala Daerah dalam Pelestarian dan Pengembangan Bahasa Negara dan Bahasa Daerah.

8) Peraturan Menteri Pendidikan Nasional Nomor 24 tahun 2007 tentang Standar Sarana dan Prasarana untuk Sekolah Dasar/Madrasah Ibtidaiyah (SD/MI), Sekolah Menengah Pertama (SMP/MTs), dan Sekolah Menengah Atas/Madrasah Aliyah (SMA/MA).

9) Peraturan Menteri Pendidikan dan Kebudayaan Republik Indonesia Nomor 23 Tahun 2015 tentang Penumbuhan Budi Pekerti.

10) Rencana Strategis Kementerian Pendidikan dan Kebudayaan 2015-2019. 
Dapat disimpulkan bahwa yang menjadi landasan hukum pemerintah dalam mengadakan program Gerakan Literasi Sekolah adalah Undang-Undang, Peraturan Pemerintah dan Peraturan Menteri yang mengatur atau berisi tentang pentingnya literasi atau kegiatan membaca menulis. Hal-hal yang mendukung, manfaat fasilitas, dan tujuan yang dicapai dalam kegiatan tersebut.

\section{Pengertian Gerakan Literasi Sekolah (GLS)}

1) Pengertian Literasi dalam konteks GLS adalah "kemampuan mengakses, memahami, dan menggunakan sesuatu secara cerdas melalui berbagai aktivitas, antara lain membaca, melihat, menyimak, menulis, dan berbicara." (Pangesti Wiedarti, 2016. h.5)

GLS merupakan suatu usaha atau kegiatan yang bersifat partisipatif dengan melibatkan warga sekolah (peserta didik, guru, kepala sekolah, tenaga kependidikan, pengawas sekolah, Komite Sekolah, orang tua/wali murid peserta didik), akademisi, penerbit, media massa, masyarakat dan pemangku kepentingan di bawah koordinasi Direktorat Jenderal Pendidikan Dasar dan Menengah Kementerian Pendidikan dan Kebudayaan.

GLS adalah gerakan sosial dengan dukungan kolaboratif berbagai elemen. Upaya yang ditempuh untuk mewujudkannya berupa pembiasaan membaca peserta didik. Pembiasaan ini dilakukan dengan kegiatan 15 menit membaca. Ketika pembiasaan membaca terbentuk, selanjutnya akan diarahkan ke tahap pengembangan, dan pembelajaran.

Variasi kegiatan dapat berupa perpaduan pengembangan keterampilan reseptif maupun produktif. Keterampilan reseptif seperti keterampilan membaca dan menyimak. Keterampilan produktif diantaranya adalah keterampilan menulis dan berbicara. (Pangesti Wiedarti, 2016. h.7)

Dari penjelasan di atas dapat disimpulkan bahwa Gerakan Literasi Sekolah adalah suatu gerakan kolaboratif yang melibatkan warga sekolah, masyarakakat, akdemisi dan pihak-pihak di bawah koordinasi Kemendikbud. Kegiatan ini ditempuh untuk menumbuhkan pembiasaan pada peserta didik. Pembiasaan ini berupa kegiatan membaca selama 15 menit. Variasi kegiatan literasi bisa berupa keterampilan reseptif dan produktif.

Literasi secara umum bertujuan untuk Menumbuhkembangkan budi pekerti peserta didik melalui pembudayaan ekosistem literasi sekolah yang diwujudkan dalam Gerakan Literasi Sekolah (GLS) agar mereka menjadi pembelajar sepanjang hayat.

\section{Komponen Literasi}

Ferguson menjabarkan bahwa komponen literasi informasi yang terdiri atas literasi dasar, literasi perpustakaan, literasi media, literasi teknologi, dan literasi visual. Komponen literasi tersebut dijelaskan sebagai berikut.(https://meenta.net/konsep-dankomponen-literasi/. By Krisnan | Desember 11, 2017) 


\section{a. Literasi Dini (Early Literacy)}

Literasi Dini (Early Literacy), yaitu kemampuan untuk menyimak, memahami bahasa lisan, dan komunikasi melalui gambar dan lisan yang dibentuk oleh pengalamannya berinteraksi dengan lingkungan sosialnya di rumah. Pengalaman peserta didik dalam komunikasi dengan bahas ibu menjadi fondasi perkembangan literasi dasar.

b. Literasi Dasar (Basic Literacy)

Literasi Dasar (Basic Literacy), yaitu kemampuan untuk mendengarkan, berbicara, membaca, menulis, dan menghitung (counting) berkaitan dengan kemampuan analisis untuk memperhitungkan (calculating), mempersepsikan informasi (perceiving), mengomunikasikan, serta menggambarkan informasi (drawing) berdasarkan pemahaman dan pengambilan kesimpulan pribadi.

c. Literasi Perpustakaan (Library Literacy)

Literasi Perpustakaan (Library Literacy), antara lain, memberikan pemahaman cara membedakan bacaan fiksi dan nonfiksi, memanfaatkan koleksi referensi dan periodikal, memahami Dewey Decimal System sebagai klasifikasi pengetahuan yang memudahkan dalam menggunakan 6 Panduan Gerakan Literasi Sekolah di Sekolah Menengah Atas perpustakaan, memahami penggunaan katalog dan pengindeksan, hingga memiliki pengetahuan dalam memahami informasi ketika sedang menyelesaikan sebuah tulisan, penelitian, pekerjaan, atau mengatasi masalah.

d. Literasi Media (Media Literacy)

Literasi Media (Media Literacy), yaitu kemampuan untuk mengetahui berbagai bentuk media yang berbeda, seperti media cetak, media elektronik (media radio, media televisi), media digital (media internet), dan memahami tujuan penggunaannya.

e. Literasi Teknologi (Technology Literacy)

Literasi Teknologi (Technology Literacy), yaitu kemampuan memahami kelengkapan yang mengikuti teknologi seperti peranti keras (hardware), peranti lunak (software), serta etika dan etiket dalam memanfaatkan teknologi. Berikutnya, kemampuan dalam memahami teknologi untuk mencetak, mempresentasikan, dan mengakses internet. Dalam praktiknya, juga pemahaman menggunakan computer (Computer Literacy) yang di dalamnya mencakup menghidupkan dan mematikan komputer, menyimpan dan mengelola data, serta mengoperasikan program perangkat lunak. Sejalan dengan membanjirnya informasi karena perkembangan 
teknologi saat ini, diperlukan pemahaman yang baik dalam mengelola informasi yang dibutuhkan masyarakat.

f. Literasi Visual (Visual Literacy)

Literasi Visual (Visual Literacy), adalah pemahaman tingkat lanjut antara literasi media dan literasi teknologi, yang mengembangkan kemampuan dan kebutuhan belajar dengan memanfaatkan materi visual dan audiovisual secara kritis dan bermartabat. Tafsir terhadap materi visual yang tidak terbendung, baik dalam bentuk cetak, auditori, maupun digital (perpaduan ketiganya disebut teks multimodal), perlu dikelola dengan baik. Bagaimanapun di dalamnya banyak manipulasi dan hiburan yang benar-benar perlu disaring berdasarkan etika dan kepatutan.

Dalam konteks SMA, contoh kegiatan literasi dipaparkan sebagai berikut.

\section{Penelitian Relevan}

Penelitian yang sejenis dengan penelitian penulis adalah sebagai berikut;

Implementasi Gerakan Literasi Sekolah (GLS) (Studi Pada SMAN 2 Malang. Penelitian ini ditulis oleh: Tristiana, Azizah Ajeng (2017) Malang. Sarjana thesis, Universitas Brawijaya. Indonesian Abstract (http://repository.ub.ac.id/6153/)

Penelitian ini dilakukan untuk mengetahui bagaimana implementasi Gerakan Literasi Sekolah (GLS) di SMAN 2 Malang, yang diperkuat dengan gerakan penumbuhan budi pekerti sebagaimana dituangkan dalam Peraturan Menteri Pendidikan dan Kebudayaan Nomor 23 Tahun 2015. Penelitian ini dengan teori Implementasi Edward III menggunakan pendekatan top-down yang meliputi variabel: komunikasi, sumber daya manusia, disposisi, dan struktur birokrasi. Penelitian ini dengan tujuan (1) untuk mengetahui gambaran tentang implementasi Gerakan Literasi Sekolah (GLS) di SMAN 2 Malang pada tahap pembiasaan, pengembangan, dan pembelajaran; (2) mengetahui faktor implementasi yang sesuai dengan model kebijakan Edward III yaitu, komunikasi, sumber daya, disposisi dan struktur birokrasi Metode penelitian yang digunakan adalah jenis penelitian deskriptif dengan pendekatan kualitatif. Teknik pengumpulan data yang digunakan adalah wawancara. Fokus pada penelitian adalah (1) Gerakan Literasi Sekolah (GLS) di SMAN 2 Malang pada tahap pelaksanaan, yaitu pembiasaan, pengembangan, dan pembelajaran; (2) faktor yang mempengaruhi implementasi Gerakan Literasi Sekolah (GLS). Metode analisis data dalam penelitian ini menggunakan model interaktif Miles, Huberman, dan Saldana. Hasil penelitian, kegiatan Gerakan Literasi Sekolah mempunyai lima komponen literasi yaitu literasi dasar, literasi perpustakaan, literasi media, literasi teknologi, dan literasi visual. Namun di SMAN 2 Malang masih pada literasi dasar, literasi perpustakaan dan telah menghasilkan beberapa program kegiatan GLS. Selanjutnya implementasi GLS di SMAN 2 Malang telah terlaksana dengan baik sesuai teori Edward III (1980). 


\section{Metodologi Penelitian}

\section{A. Tipe Penelitian}

Berdasarkan jenisnya Penelitian ini menggunakan metode kualitatif. Krik dan Miller mendefinisikan bahwa penelitian kualitatif adalah tradisi tertentu dalam ilmu pengetahuan sosial yang secara fundamental bergantung pengamatan pada manusia dalam kawasannnya sendiri dan berhubungan dengan orang-orang tersebut dalam bahasanya dan dalam peristilahannya. (Lexy J Moleong. 2002. h.3)

Pendekatan kualitatif yaitu merupakan suatu proses penelitian dan pemahaman yang berdasarkan pada metodologi yang menyelidiki suatu fenomena sosial dan masalah manusia. Pada pendekatan ini, peneliti membuat suatu gambaran komplek, meneliti kata-kata, laporan terinci dari pandangan informan, dan melakukan studi pada situasi yang alami. (Sukarman Syarnubi, 2011. h. 29)

Penelitian kualitatif adalah penelitian yang bermaksud untuk memahami fenomena tentang apa yang dialami oleh subjek penelitian misalnya perilaku, persepsi, motivasi, tindakan, dll. Secara holistik, dan dengan cara deskripsi dalam bentuk kata-kata dan bahasa, pada suatu konteks khusus yang alamiah dan dengan memanfaatkan berbagai metode alamiah. (Lexy J Moleong. 2015. h.6)

Berdasarkan definisi tersebut dapat diambil kesimpulan bahwa penelitian yang menghasilkan data deskriptif berupa kata-kata tertulis atau lisan dari orang-orang atau perilaku yang dapat diamati dan hasil penemuannya bukan dengan jalan pengukuran angka-angka atau statistik.

Dalam penelitian ini, peneliti menggunakan beberapa cara mengumpulkan data..

\section{Interview/Wawancara Semi terstruktur}

Jenis wawancara ini dimana dalam pelaksanaannya lebih bebas bila dibandingkan dengan wawancara terstruktur. Tujuan dari wawancara jenis ini adalah untuk menemukan permasalahan secara lebih terbuka, dimana pihak yang diajak wawancara diminta pendapat dan ide-idenya. Dalam melakukan wawancara, peneliti perlu mendengarkan secara teliti dan mencatat apa yang dikemukakan oleh imporman. ( Maryaai, Kun dan Juju Suryawati. 2007)

Tabel 1.4 Pedoman Wawancara

\begin{tabular}{|l|l|l|c|}
\hline \multicolumn{1}{|c|}{ Fokus Penelitian } & \multicolumn{1}{|c|}{$\begin{array}{c}\text { Sub } \\
\text { Penelitian }\end{array}$} & \multicolumn{1}{|c|}{ Indikator } & $\begin{array}{c}\text { No } \\
\text { Soal }\end{array}$ \\
\hline Implemntasi & Komunikasi \\
Gerakan literasi & & Kebijakan kepada seluruh & 1 \\
sekolah & & elemen serta sikap dan & 2 \\
& & tanggapan dari para pihak yang & 3 \\
& & terlibat & \\
\cline { 2 - 4 } & Sumber Daya & Ketersediaan sumber daya dalam & 4 \\
& & mendukung kebijakan & 5 \\
\hline
\end{tabular}




\begin{tabular}{|c|c|c|c|}
\hline & & & 6 \\
\hline & Disposisi & $\begin{array}{l}\text { Komitmen para aktor dalam } \\
\text { melaksanakan kebijakan tersebut }\end{array}$ & $\begin{array}{c}8 \\
9 \\
10\end{array}$ \\
\hline & $\begin{array}{l}\text { Struktur } \\
\text { Birokrasi }\end{array}$ & $\begin{array}{l}\text { Kesesuaian organisasi birokrasi } \\
\text { yang menjadi penyelenggara } \\
\text { implementasi kebijkan }\end{array}$ & $\begin{array}{l}11 \\
12 \\
13 \\
\end{array}$ \\
\hline \multirow{2}{*}{$\begin{array}{l}\text { Perkembangan Pasca } \\
\text { Implementasi } \\
\text { Gerakan Literasi } \\
\text { Sekolah }\end{array}$} & $\begin{array}{l}\text { Keterampilan } \\
\text { Membaca }\end{array}$ & $\begin{array}{l}\text { a. Minat Membaca } \\
\text { b. Hasil Bacaan }\end{array}$ & $\begin{array}{l}14 \\
15\end{array}$ \\
\hline & $\begin{array}{l}\text { Keterampilan } \\
\text { Menulis }\end{array}$ & $\begin{array}{l}\text { a. Minat menulis } \\
\text { b. Hasil tulisan }\end{array}$ & $\begin{array}{l}16 \\
17\end{array}$ \\
\hline
\end{tabular}

\section{Observasi Nonpartisipan}

Dalam observasi nonpartisipan peneliti tidak tetlibat dan hanya sebagai pengamat peneliti mencatat, menganalisis dan selanjutnya dapat membuat kesimpulan. (Suharsimi Arikunto, 2002, h. 154) ini dibagi menjadi dua jenis yaitu observasi terstruktur dan observasi tidak terstruktur oleh observasi yang telah dirancang secara sistematis tentang apa yang akan diamati, sedangkan observasi tidak terstuktur adalah observasi yang tidak di disiapkan secara sistematis tentang apa yang akan diobservasi karena peneliti tidak tahu secara pasti tentang apa yang akan diamati.

Pengamatan yang akan dimaksud adalah pengamatan secara langsung oleh peneliti, sehingga dapat diperoleh data.

\section{Dokumentasi}

Penelitian kualitatif kebanyakan data yang diperoleh dari manusia melalui observasi, wawancara dan untuk melengkapi data tersebut dipergunakan juga tehnik pengumpulan data sebagai pelengkap yaitu studi dokumentasi. Dokumentasi dilakukan secara terperinci agar apa yang diteliti mudah untuk dipahami. Dokumentasi dilakukan agar adanya bukti dari sebuah penelitian.

Peranan dokumen dalam hal ini adalah untuk mengecek relevansi data. Menurut Sugiyono, dokumentasi merupakan catatan peristiwa yang sudah berlalu. Dokumen bisa berbentuk tulisan, gambar, atau karya-karya monumental dari seseorang. ( Sugiyono, 2010, h. 240). Dalam penelitian ini peneliti hanya akan melampirkan tulisan dan gambar. Gambar-gambar yang dilampirkan yang berkaitan dengan kegiatan gerakan literasi sekolah. 


\section{Hasil Penelitian dan Pembahasan}

\section{A. Deskripsi Lokasi Penelitian}

Yaitu Sekolah Dasar Unggulan Aisyiyah Taman Harapan Curup yang teletak di jalan KH. Ahmad Dahlan Talang Rimbo Baru, Rejang Lebong, Provinsi Bengkulu. Sekolah ini pada mulanya adalah tanah panti asuhan Aisyiyah untuk digunakan membangun asrama putra.

\section{Hasil Penelitian}

\section{Kebijakan Gerakan Literasi Sekolah di Sekolah Dasar Unggulan Aisyiyah} Taman Harapan Curup.

Berdasarkan pengertian literasi, literasi tidak dapat dipisahkan dengan kegiatan membaca dan menulis. Dalam komponen literasi kegiatan membaca dan menulis adalah literasi dasar.

Mengenai pemahaman kebijakan gerakan literasi sekolah, Ibu Enilawati sebagai wakil kepala sekolah bagian kurikulum mengatakan bahwa:

Kebijakan gerakan literasi sekolah itu adalah suatu kebijakan yang diutarakan oleh menteri pendidikan untuk seluruh warga indonesia terutama kaum pelajar, nah jadi dengan adannya kebijakan gerakan literasi sekolah ini menteri pendidikan berharap seluruh warga sekolah dapat mengembangkan kegiatan gemar membaca lagi, sebab sekarang banyak faktor yang menghambat kegiatan gemar membaca. ( Wawancara, Enilawati,Selasa 8 Mei 2018).

\section{Kemudian diungkapkan oleh Ibu Miki Famela selaku kepala perpustakaan mengenai pemahaman kebijakan gerakan sekolah yaitu:}

Di Sekolah Dasar Unggulan Aisyiyah sudah lebih dulu menggencarkan Gerakan literasi sebelum pada akhirnya pak Anies Baswedan akhirnya mengeluarkan kebijakan tersebut. tapi memang saya belum tahu secara detail bagaimana kebijakan yang dimaksud. Kemudian ada buku panduan tentang gerakan literasi sekolah yang disusun oleh kementrian pendidikan. Secara garis besar, program-program yang dirancang Sekolah Dasar Unggulan Aisyiyah tidak bersebrangan dengan pedoman dari pemerintah. (Wawancara, Miki Famela Selasa, 8 Mei 2018)

Ibu Ani Wahyuni sebagai wali kelas IV juga mengungkapkan, pemahaman mengenai kebijakan gerakan literasi sekolah yaitu: "Saya mengetahui program ini jauh sebelum diluncurkan sebelumnya. saya tertarik dengan program ini. Setelah saya cari-cari dari internet, dapetlah info tentang gerakan literasi. Saya juga mempunyai panduannya" (Wawancara, Ani Wahyuni, Selasa 8 Mei 2018) 
Dari pernyataan yang diungkapkan Ibu Enilawati, Ibu Miki Famela, dan Ibu Ani Wahyuni kebijakan gerakan literasi adalah suatu kebijakan yang diutarakan oleh menteri pendidikan untuk seluruh warga indonesia terutama kaum pelajar. Hal tersebut menyatakan bahwa sebagian besar warga sekolah telah memahami apa itu kebijakan gerakan literasi sekolah.

Adapun tanggapan wakil kepala sekolah bagian kurikulum Ibu Enilawati berkenaan dengan adanya kebijakan gerakan literasi sekolah yaitu:

Kebijakan gerakan literasi ini sangat bagus untuk mengatasi angka literasi yang rendah di indonesia. Walaupun implementasinya akan berbeda-beda disetiap satuan pendidikan disesuaikan dengan kesanggupan dari masing-masing sekolah. Kami sangat support sekali dengan kebijakan ini karena sesuai dengan kebutuhan kami di Sekolah. (Wawancara, Enilawati, Selasa $8 \mathrm{Mei}$ )

Sedangkan tanggapan dari Ibu Miki Famela berkenaan dengan adanya kebijakan gerakan literasi sekolah yaitu:

Saya sangat mendukung kebijakan tersebut, bahkan saya selaku Staf perpustakaan di SDUA ini, sering membuat inovasi-inovasi terkait kegiatan perpustakaan untuk menunjang literasi siswa. Letak perpustakaan yang berada di luar ruangan seperti ini dapat menarik minat para siswa dan siswi untuk datang ke perpustakaan untuk membaca. ( Wawancara, Miki Famela Selasa 8 Mei 2018)

Begitu pula dengan yang disampaikan oleh Ibu Ani Wahyuni yang menegaskan bahwa: "Bagus dan sangat bermanfaat. Harapannya bisa berjalan di Sekolah Dasar Unggulan Aisyiyah dan dapat dikembangkan atau ada yang dimodifikasi agar tidak terjadi kebosanan".

Dari ungkapan Ibu Enilawati, Ibu Miki Famela, dan Ibu Ani Wahyuni jelas bahwa tanggapan pihak sekolah dengan adanya kebijakan gerakan literasi sekolah sangat baik untuk mengatasi angka literasi yang rendah. Pernyataan mereka sesuai dengan lingkungan yang diciptakan Sekolah Dasar Unggulan Aisyiyah itu sendiri.

Sedangkan yang berkaitan dengan kegiatan yang menunjang kebijakan gerakan literasi sekolah sangat banyak seperti yang disampaikan oleh Ibu Enilawati;

Sebelum Dinas menginstruksikan untuk membuat program yang menunjang kebijakan gerakan literasi sekolah, kami hanya melakukan upaya mix and match dari apa yang diinginkan oleh Dinas. Hal ini dikarenakan program untuk menunjang literasi sudah ada sebelum kebijakan ini resmi disosisalisasikan. Program-program yang menunjang kegiatan literasi di SD Unggulan Aisyiyah yaitu program membaca dipagi hari dan yang akan lebih banyak berkaitan dengan literasi adalah perpustakaan. Selain program yang sudah disebutkan tadi, kebijakan gerakan literasi sekolah ini 
juga dimasukkan kedalam kurikulum sekolah khususnya Bahasa. Maka dari itu untuk anak kelas 1 dan 2 lebih banyak mata pelajaran bahasa untuk tahap pembiasaan. Dibentuk juga Reading Group dikelas untuk menunjang pembelajaran bahasa di kelas. Di perpustakaan juga banyak program-program yang menarik untuk menggalakan kegiatan literasi siswa. Didalam kelas juga terdapat mini library atau biasa dikenal pojok bahasa yang bertujuan agar anak dekat dengan buku. Untuk lebih lengkap lagi saya rekomendasikan untuk mewawancarai kepala perpustakaan karena dari perpustakaan yang akan lebih banyak membuat program berkaitan dengan literasi. (Wawancara, Enilawati, Selasa 8 Mei)

\section{Hal yang disampaikan oleh Ibu Enilawati, diperjelas oleh pernyataan Ibu Miki Famela,}

Banyak sekali program perpustakaan yang menunjang aktivitas literasi siswa. Diantaranya: story telling, morning motivasi yang dilakukan oleh umi dan ustad setiap paginya, library class, Best Reader of The Month, Books Lover, World Book Day, Waqaf Buku, Membumi (Membaca Buku Sepuluh Menit), mading, dan masih banyak lagi. Itu adalah program yang langsung dihandle oleh perpustakaan. Karena ada beberapa program yang menunjang literasi tapi programnya itu masuk kedalam kurikulum secara langsung. ${ }^{1}$

\section{Ibu Ani Wahyuni, juga menyampaikan kegiatan yang menunjang kegiatan literasi yaitu}

"Kegiatan yang menunjang kegiatan literasi adalah dengan dijadwalkannya kegiatan literasi setiap hari dengan waktu minimal 15 menit dan dengan adanya pojok baca di dalam setiap kelas yang mempermudah anak-anak memperoleh sumber literasi. $^{2}$

Berdasarkan hasil observasi kegiatan literasi kelas di kelas IV Al-Khaafidh, jadwal yang ada di kelas tersebut berbeda setiap harinya. Kegiatan literasi biasanya dilakukan dikelas dan diluar kelas. Kegiatan literasi diluar kelas di lakukan di perpustakaan, green house, sang juara, agreeduo, dan pojok baca yang ada diluar kelas. Dengan adanya pojok baca di lingkungan sekolah, green house, perpustakaan mini, dan kegiatan perpustakaan, green house, sang juara, dan agreeduo pihak sekolah telah menyediakan sarana dan prasaran untuk menunjang kebijakan gerakan literasi sekolah.

Ditinjau dari syarat implmentasi kebijakan yang berhubungan dengan gerakan literasi sekolah berkaitan dengan sasaran kebijakan sosialisasi tentang kebijakan

\footnotetext{
WIB.

${ }^{1}$ Wawancara dengan ibu Miki Famela S.Pd.I, kepala perpustakaan, pada hari Selasa 8 Mei 2018, pukul 07.30

${ }^{2}$ Wawancara dengan ibu Ani Wahyuni S.Pd.I, wali kelas IV, pada hari Selasa 8 Mei 2018, pukul 09.00 WIB.
} 
kepada organisasi dan/atau publik serta para agen pelaksana yang terlibat. Komunikasi dalam implementasi kebijakan Gerakan Literasi Sekolah di SDUA THC dilakukan baik secara internal maupun eksternal. Sosialisasi dilakukan melalui surat pemberitahuan dari sekolah kepada orangtua. Pernyataan ini disampaikan oleh Ibu

\section{Enilawati:}

Untuk sosialisasi sekolah memberikan surat pemberitahuan bahwa siswa telah menerima jadwal literasi. Jadi, sekolah tidak hanya melaksanakan sholat duha dan mengaji tetapi juga melaksanakan kegiatan literasi sekolah. Selain memberikan surat pemberitahuan sekolah juga bersosialisasi melalui grup whatsapp yang pada masingmasing kelas memiliki grup whatsapp. Bentuk sosialisasi lainnya yaitu terdapat banyaknya poster-poster dan tempat membaca. Ketika wali murid bertanya mengenai penggunaan pengadaan tempat membaca, guru dapat secara langsung bersosialisasi mengenai kegiatan literasi sekolah. ${ }^{3}$

Untuk program-program penunjang literasi yang diinisiasi oleh perpustakaan, penyebaran informasinya bersifat internal karena program-program lebih banyak diperuntukkan dan melibatkan internal sekolah walaupun ada beberapa program yang melibatkan orangtua siswa. Hal ini disampaikan oleh Ibu Miki Famela, bahwa;

Dalam tahap sosialisasi penyebaran informasinya bersifat internal tidak keluar sekolah. berikut penjelasan dari Pertama-tama diforum guru-guru lalu dibuatkan surat kepada orangtua. Dan surat pemberitahuan itu akan diberikan kepada wali kelas siswa untuk nantinya wali kelas siswa dapat memberikan informasi kepada orangtua. Selain itu, sebagai bentuk publikasi aktivitas apa saja yang sudah dilakukan, foto-foto kegiatan akan dimuat dikalender perpustakaan dan media sosial sekolah. Kalau untuk warga sekolah biasanya disampaikan melalui grup whatsapp sekolah yang berisi guru-guru dan karyawan. ${ }^{4}$

Peneliti juga mewawancarai Ibu Ani Wahyuni, selaku Wali kelas. Berikut ini jawaban beliau ketika ditanyai terkait sosialisasi kebijakan terkait literasi sekolah:

Kalau untuk kegiatan-kegiatan yang sifatnya langsung dari sekolah, tentu guru-guru akan selalu menjadi target utama apalagi tentang literasi. Karna kan

\footnotetext{
${ }^{3}$ Wawancara dengan ibu Enilawati S.Pd.I, wakil kepala sekolah, hari Selasa 8 Mei, pukul 11.30 WIB.

${ }^{4}$ Wawancara dengan ibu Miki Famela S.Pd.I, kepala perpustakaan, pada hari Selasa 8 Mei 2018, pukul 07.30 WIB.
} 
kami juga yang akhirnya harus mem breakdown program itu ke adik-adik. Kalau untuk program dari perpustakaan biasanya guru-guru diingatkan di whatsapp. ${ }^{5}$

Namun pada saat kegiatan observasi peneliti tidak menemukan brosur ataupun poster-poster berkaitan dengan kegiatan literasi. Brosur atau poster yang ada hanya prestasi-prestasi dari sekolah itu sendiri. Hal ini di sebabkan karena kegiatan literasi sudah cukup lama diterapkan di Sekolah Dasar Unggulan Aisyiyah.

Dari syarat implementasi kebijakan dalam tahap sasaran kebijakan drajat ketepatan dan kejelasan sudah dipahami tidak hanya pihak internal tetapi termasuk pihak eksternal pengguna kebijakan. Semua pihak dapat memberikan dukungan terhadap pelaksanaan tersebut.

Berdasarkan syarat implementasi kebijakan yang berkaitan dengan sumber daya meliput sebagai berikut:

1) Sumber Daya Manusia

Diperlukannya sumber daya manusia untuk mendukung berjalannya sebuah kebijakan. Berdasarkan hasil penelitian didapat bahwa seluruh elemen sekolah menjadi agen pelaksana kebijakan Gerakan Literasi Sekolah ini. Hal ini juga disampaikan oleh ibu Enilawati S.Pd.I ketika diwawancarai terkait sumber daya yang terlibat untuk kebijakan Gerakan Literasi Sekolah: " semua warga sekolah dimulai dari kepala sekolah, wakil kepala, staf, tata usaha, dan wali siswa terlibat dalam pelaksanaan kebijakan literasi. ${ }^{6}$

Pendapat ini diperkuat oleh apa yang disampaikan Ibu Miki Famela, kepada peneliti bahwa; "semua warga sekolah dilibatkan mulai dari kepala sekolah, dewan guru, para staf bahkan wali siswa".?

Sama halnya dengan apa yang disampaikan oleh Ibu Ani Wahyuni, "untuk sumber daya manusia semua di ikut sertakan tanpa terkecuali. Hal ini sudah seperti kewajiban yang hendaknya di laksanakan oleh semua warga sekolah". 8

Dari hasil observasi berkaitan dengan sumber daya manusia di Sekolah Dasar Unggulan Aisyiyah terdapat banyak guru, karyawan, serta wali siswa atau orang tua yang akan mendukung kebijakan gerakan literasi sekolah.

2) Sumber Dana

Berdasarkan wawancara didapatkan hasil bahwa secara khusus memang ada anggaran untuk kebijakan Gerakan Literasi Sekolah, namun,

\footnotetext{
${ }^{5}$ Wawancara dengan ibu Ani Wahyuni S.Pd.I, wali kelas IV, pada hari Selasa 8 Mei 2018, pukul 09.00 WIB.

${ }^{6}$ Wawancara dengan ibu Enilawati S.Pd.I, wakil kepala sekolah, hari Selasa 8 Mei, pukul 11.30 WIB.

${ }^{7}$ Wawancara dengan ibu Miki Famela S.Pd.I, kepala perpustakaan, pada hari Selasa Senin 8 Mei 2018, pukul 07.30 WIB.

${ }^{8}$ Wawancara dengan ibu Ani Wahyuni S.Pd.I, wali kelas IV, pada hari Selasa 8 Mei 2018, pukul 09.00 WIB.
} 
harus di minimalisir dengan sebab adanya prinsip bahwa dengan pendanaan seminimal mungkin dapat melakukan kegiatan literasi sekolah dengan baik. Seperti apa yang disampaikan oleh Ibu Enilawati, bahwa "Untuk pendanaan memang ada alokasinya secara khusus untuk gerakan literasi sekolah tetapi harus diminimalisir karena kita berprinsip dengan pendanaan yang seminimal mungkin dapat melakukan kegiatan literasi".

\section{Ibu Ani Wahyuni menyatakan hal yang sama seperti ibu Enilawati bahwa:}

Kalau dari sekolah, sudah anggarannya sendiri untuk setiap divisi. Nanti ketika rapat kerja, seluruh divisi diminta untuk membuat anggaran. Sehingga program-program yang terintegrasi dari kurikulum bisa juga mendapatka alokasi dana. ${ }^{10}$

Data ini juga diperkuat oleh apa yang disampaikan oleh Ibu Miki Famela,

Setiap tahun perpustakaan mendapat anggaran tersendiri untuk sirkulasi dan kegiatan-kegiatan ringan lainnya. Tapi untuk buku, sekolah sudah mempunyai alokasi khusus menggunakan dana BOS dari pemerintah untuk pengadaan buku. Selain itu, untuk program-program besar juga kita biasa mengajukan proposal kegiatan kepada orangtua siswa yang memang memiliki unit usaha. Sehingga tidak ada kendala untuk pendanaan. Dan juga adanya sumbangan dari siswa dan siswi yang telah lulus. ${ }^{11}$

3) Alokasi Waktu

Berdasarkan hasil wawancara yang dilakukan di lapangan peneliti mendapati bahwa SDUA THC mengalokasikan waktu khusus untuk programprogram yang menunjang kebijakan GLS ini selama 15 menit. Karena peningkatan literasi siswa merupakan tujuan yang diinginkan oleh sekolah. Hal ini diperkuat oleh apa yang disampaikan oleh Ibu Enilawati, "Untuk alokasi wakktu minimal waktu yang digunakan 15 menit untuk melakukan kegiatan literasi kelas". ${ }^{12}$

Hal ini senada dengan yang disampaikan oleh Ibu Miki Famela, bahwa "Tentu kita sudah mengalokasi waktu untuk program-program tersebut.

\footnotetext{
${ }^{9}$ Wawancara dengan ibu Enilawati S.Pd.I, wakil kepala sekolah, hari Selasa 8 Mei, pukul 11.30 WIB.

${ }^{10}$ Wawancara dengan ibu Ani Wahyuni S.Pd.I, wali kelas IV, pada hari Selasa 8 Mei 2018, pukul 09.00 WIB. 07.30 WIB.

${ }^{11}$ Wawancara dengan ibu Miki Famela S.Pd.I, kepala perpustakaan, pada hari Selasa 8 Mei 2018, pukul

${ }^{12}$ Wawancara dengan ibu Enilawati S.Pd.I, wakil kepala sekolah, hari Selasa 8 Mei, pukul 11.30 WIB.
} 
dibuatkan matriks juga supaya kita bisa ingat terus dibulan ini harus berjalan program apa dan seterusnya. Dan kita sesuaikan dengan program-program kelas". ${ }^{13}$

Sehingga dapat disimpulkan bahwa pihak sekolah sudah mengalokasikan waktu khusus sebagai upaya untuk peningkatan literasi siswa, bahwa sekolah telah mengalokasikan waktu untuk kegiatan literasi ini.

Sedangkan komitmen dari agen-agen memiliki pengaruh yang kuat dalam pelaksanaan suatu kebijakan. Berikut ini gambaran komitmen agen pelaksana berdasarkan ibu Enilawati S.Pd.I, "Komitmen dari masing-masing agen dari seluruh pelaku semuanya mengikuti aturan sekolah para agen mengikuti dengan baik. Para agen sangat berkomitmen dalam mendukung kebijakan literasi sekolah ini”. ${ }^{14}$

Ibu Miki Famela S.Pd.I, juga menyampaikan bahwa "Semua berkomitmen dan guru-guru yang bersangkutan ikut terlibat aktif dalam program yang dibuat oleh perpustakaan". ${ }^{15}$

Ibu Ani Wahyuni S.Pd.I, menyampaikan bahwa: "Biasanya kadiv akademik dan kurikulum suka memberikan orientasi dulu tentang suatu program. Supaya guru-guru paham seberapa urgent program ini untuk diterapkan ke anakanak. Kalau terkait kemampuan manajerial, ya kita sering juga dapet pelatihanpelatihan, diminta ikut seminar tertentu, dan ada juga yang diberi beasiswa dari sekolah". ${ }^{16}$

Hal ini juga sejalan dengan hasil penelitian yang dilakukan peneliti di lapangan bahwa seluruh warga turut aktif mengimplementasikan kebijakan tersebut. Untuk kemampuan manajerial, pihak sekolah memfasilitasi para guru untuk terlibat dalam seminar, pelatihan, bimbingan teknis dan melanjutkan studi agar tidak gagap merespon kebijakan yang telah ditetapkan.

Sedangkan struktur birokrasi dalam kebijakan gerakan literasi sekolah ini dikendali secara langsung oleh pihak yayasan dan kepala sekolah. seperti apa yang disampaikan oleh ibu Enilawati S.Pd.I, bahwa;

Struktur birokrasi untuk di SDUA ini berdasarkan rapat pengurus yayasan dan kepala sekolah beserta WAKA. Kemudian kebijakan-kebijakan melalui pengurus yayasan dan kepala sekolah beserta WAKA akan dituangkan ke seluruh

\footnotetext{
${ }^{13}$ Wawancara dengan ibu Miki Famela S.Pd.I, kepala perpustakaan, pada hari Selasa 8 Mei 2018, pukul 07.30 WIB.

${ }^{14}$ Wawancara dengan ibu Enilawati S.Pd.I, wakil kepala sekolah, hari Selasa 8 Mei, pukul 11.30 WIB. 07.30 WIB.

${ }^{15}$ Wawancara dengan ibu Miki Famela S.Pd.I, kepala perpustakaan, pada hari Selasa 8 Mei 2018, pukul WIB.

${ }^{16}$ Wawancara dengan ibu Ani Wahyuni S.Pd.I, wali kelas IV, pada hari Selasa 8 Mei 2018, pukul 09.00
} 
siswa yang nantinya akan dibagi karena kita memiliki beberapa tempat membaca. Untuk di kelas langsung dikoordinir oleh wali kelas baik itu pojok baca dan lain sebagainya. Jadi, Struktur teratas adalah rapat pengurus dan kepala sekolah, dibawahnya ada para WAKA kemudian koordinator tiap ruang baru setelah itu wali kelas. Sedangkan untuk program-program yang disusun oleh perpustakaan. ${ }^{17}$

\section{Ibu Miki Famela, menyampaikan mengenai struktur birokrasi yang terjadi sebagai berikut;}

Untuk program-program perpustakaan dirancang tentunya di dalam internal pengurus perpustkaan itu terlebih dahulu, kemudian ketika konsepnya sudah matang, saya selaku kepala perpustakaan akan berbicara dengan kepala sekolah. Jika program disetujui oleh kepala sekolah, maka nantinya akan dibuatkan surat pemberitahuan kepada guru dan karyawan agar ikut membantu pelaksanaan program tersebut. kurang lebih seperti itu struktur birokrasinya. ${ }^{18}$

Sedangkan menurut Ibu Ani Wahyuni, menyampaikan bahwa, "Kebijakannya dari atas nanti diteruskan kebawah. Kebiasaannya nanti dari kepala sekolah secara struktur melalui rapat guru lalu ke pihak-pihak yang berkaitan tergantung dari programnya". ${ }^{19}$

Bahwa garis struktur birokrasi kebijakan terkait literasi sekolah adalah dari pihak manajemen akan menyampaikan program yang diusulkan untuk kemudian disetujui oleh pengurus yayasan dan kepala sekolah. Program yang sudah disetujui kemudian disosialisasikan kepada pihak-pihak yang terkait agar diberikan arahan mengenai program yang akan dilaksanakan.

Kemampuan yang diperoleh semenjak diimplementasikannya kebijakan gerakan literasi sekolah menurut ibu Enilawati adalah:

Semenjak diterapkannya Gerakan Literasi Sekolah kemampuan berbahasa anak meningkat.

Misalnya ketika anak di berikan tugas bercerita di depan kelas anak sudah mulai berani. Sebab dari kegiatan literasi siswa dibiasakan bercerita didepan kelas. Jadi kegiatan literasi selama 15 menit di kelas dibuat bervariasi oleh para wali kelas. ${ }^{20}$ $07.30 \mathrm{WIB}$

${ }^{17}$ Wawancara dengan ibu Enilawati S.Pd.I, wakil kepala sekolah, hari Selasa 8 Mei, pukul 11.30 WIB.

18 Wawancara dengan ibu Miki Famela S.Pd.I, kepala perpustakaan, pada hari Selasa 8 Mei 2018, pukul

${ }^{19}$ Wawancara dengan ibu Ani Wahyuni S.Pd.I, wali kelas IV, pada hari Selasa 8 Mei 2018, pukul 09.00 WIB.

${ }^{20}$ Wawancara dengan ibu Enilawati S.Pd.I, wakil kepala sekolah, hari Selasa 8 Mei, pukul 11.30 WIB. 
Sedangkan menurut Ibu Miki Famela:"saya rasa kemampuan yang diperoleh banyak, kemampuan siswa mulai muncul semenjak kebijakan gerakan literasi ini di lakukan. Kemampuan membaca siswa meningkat dan tulisan siswa lebih rapi. Dengan adanya kebijakan gerakan literasi sekolah siswa jadi terbiasa membaca dan menulis". ${ }^{21}$ Dari pernyataan Ibu Ani Wahyuni dan Ibu Miki Famela diperjelas oleh Ibu Ani Wahyuni bahwa:

Berkaitan dengan kemampuan jelas kemampuan yang diperoleh siswa adalah kemampuan berbahasa siswa mulai dari kemampuan membaca, kemapuan menulis, kemampuan mendengarkan, dan kemampuan berbicara sangat meningkat. Kami membiasakan siswa dalam kegiatan literasi yaitu siswa tidak hanya sekedar membaca namun siswa juga dilatih untuk menulis sesuai dengan tanda baca dan lain sebagainya. Nah untuk kemampuan mendengarkan biasanya para guru atau wali kelas akan bercerita atau membacakan cerita yang nantinya siswa akan kami tunjuk untuk bercerita kembali baik itu diceritakan di depan kelas atau menuliskannya ke dalam buku tulis tentunya dengan tanda baca dan lain sebagainya. Dari kegiatan siswa tidak hanya membaca dan menulis saja melainkan siswa juga memperoleh kemampuan mendengarkan dan kemampuan berbicara. $^{22}$

Hasil observasi yang didapat peneliti kemampuan yang diperoleh siswa adalah kemampuan berbahasa dapat dilihat dari nilai akhir siswa dimana nilai literasi dimasukkan ke dalam penilaian Bahasa Indonesia. Kegiatan di dalam kelas juga bervariasi siswa tidak hanya dituntut membaca dan menulis saja. Namun juga dituntut untuk berani tampil percaya diri, menambah wawasan agar minat membacanya meningkat.

\section{Faktor Pendukung dan Penghambat Implementasi Kebijakan Gerakan Literasi Sekolah di Sekolah Dasar Unggulan Aisyiyah Taman Harapan Curup}

\section{a. Faktor Pendukung}

Sebuah kebijakan dapat berhasil dilaksanakan apabila memiliki faktorfaktor yang mendukung terlaksananya kebijakan tersebut. Dari hasil penelitian, berikut ini adalah faktor pendukung terlaksananya kebijakan Gerakan Literasi Sekolah di SDUA THC:

1) Terdapat sarana dan prasarana dalam mensosialisasikan kebijakan atau program baru dari sekolah. Sarana itu berupa rapat kerja yayasan, rapat kerja guru, pertemuan wali siswa, dan masih banyak sarana yang lain untuk menyampaikan kebijakan yang sudah dirancang.

\footnotetext{
${ }^{21}$ Wawancara dengan ibu Miki Famela S.Pd.I, kepala perpustakaan, pada hari Selasa 8 Mei 2018, pukul 07.30 WIB

${ }^{22}$ Wawancara dengan ibu Ani Wahyuni S.Pd.I, wali kelas IV, pada hari Selasa 8 Mei 2018, pukul 09.00 WIB.
} 
2) Adanya perkembangan media yang juga sangat membantu.

3) Terdapat aloakasi waktu dan dana untuk menunjang kecakapan literasi siswa.

4) terdapat alokasi dana untuk membuat poster, surat edaran, dan untuk kegiatan yang akan dilaksanakan.

5) Semua warga sekolah terlibat aktif dalam program yang dibuat oleh perpustakaan.

\section{b. Faktor Penghambat}

1) Kesibukkan masing-masing umi dan ustad yang biasanya menjadikan proses literasi di perpustakaan dan pembuatan mading yang mendadak karena keterbatasan sumber daya manusia juga.

2) Anak-anak terlihat bosan sebab buku-buku yang menarik sulit didapat.

3) Orang tua sering mengabaikan pesan masuk melalui whatshapp.

4) Perlu adanya pengembangan program agar tidak monoton dan terjadi kebosanan.

\section{B. Pembahasan Hasil Penelitian}

Dari data dan analisis data dengan menggunakan teknik pengumpulan data melalui observasi, wawancara dan dokumentasi. Peneliti akan menarik suatu pembahasan yang mencakup dibawah ini:

\section{Implementasi Kebijakan Gerakan Literasi Sekolah di Sekolah Dasar Unggulan Aisyiyah Taman Harapan Curup}

Komunikasi berkaitan dengan sosialisasi tentang kebijakan kepada organisasi dan/atau publik serta para agen pelaksana yang terlibat. Di SDUA, sosialisasi program dilakukan melalui:

a) Rapat kerja yang diikuti oleh seluruh elemen sekolah baik guru, kepala sekolah dan seluruh karyawan. Rapat kerja ini biasa dilakukan diawal semester. Rapat kerja berfungsi untuk menentukan program-program yang akan dilakukan di semester selanjutnya dan mensosialisasikan apa saja peran dari masing-masing agen yang ada di sekolah.

b) Rapat manajemen sekolah yang terdiri dari kepala sekolah dan staff yang berkaitan dengan manajemen sekolah. Rapat manajemen dilaksanakan sesuai dengan kebutuhannya. Tidak ada alokasi waktu kapan diadakan rapat manajemen, tetapi intensitas rapat manajemen masih lebih banyak jika dibandingkan dengan rapat kerja.

c) Surat pemberitahuan kepada orangtua. Hal ini merupakan upaya yang dilakukan pihak sekolah agar orangtua terlibat aktif dalam tercapainya tujuan dari sekolah. orangtua juga dituntut untuk mendukung program yang diselenggarakan sekolah. 
d) Sosialisasi juga dilakukan melalui website sekolah. dalam perjalanannya, website sekolah belum dioperasikan secara optimal sehingga postinganpostingan di website tidak diupdate secara rutin.

e) Penyebaran poster khusus untuk kegiatan-kegiatan dari perpustakaan agar seluruh elemen sekolah mengetahui program apa yang akan diselenggarakan.

f) Sosialisasi juga dilakukan melalui postingan poster via media sosial berupa whatsapp. Sekolah memiliki beberapa grup whatsapp yang melibatkan pihakpihak terkait. Grup tersebut terdiri dari grup yang berisi seluruh guru dan karyawan, grup orangtua siswa berdasarkan kelas, dan grup para guru. Hal ini dapat memudahkan sekolah untuk penyebaran informasi.

Aspek ini berkenaan dengan sumber daya pendukung untuk pelaksanaan program agar dapat berjalan dengan baik. Sumber daya tersebut meliputi:

a) Sumber daya manusia

Sumber daya manusia yang terlibat untuk mendukung kebijakan gerakan literasi sekolah di sekolah dasar unggulan Aisyiyah taman harapan Curup adalah seluruh warga sekolah baik kepala sekolah, guru, karyawan, siswa, dan orangtua siswa. Agar memiliki komitmen yang baik, dalam proses seleksi karyawan dan guru, pihak sekolah membuat tes yang terstandar. Pihak sekolah dalam hal ini kepala sekolah tidak hanya melihat dari latar belakang pendidikan si calon saja, tapi juga melihat bagaimana pandangannya terhadap dunia pendidikan, kreativitas, dan tentunya motivasi apa yang menjadikan seorang calon guru atau karyawan untuk menjadi bagian dari sekolah dasar uanggulan Aisyiyah taman harapan Curup. Sehingga diharapkan dapat terjaring guru-guru serta karyawan yang memiliki komitmen bersama untuk mencapai visi misi dan tujuan sekolah.

b) Sumber Dana

Pihak sekolah sekolah dasar unggulan Aisyiyah taman harapan Curup mengalokasikan dana sesuai dengan programnya masing-masing. Baik itu program yang bersifat kegiatan maupun penyediaan sumber informasi literasi. Alokasi dana ini digunakan untuk program-program yang menunjang budaya literasi. Sumber dana berasal dari bantuan oprasional sekolah (BOS) yang nantinya akan digunakan untuk pemenuhan kebutuhan sumber literasi berupa pengadaan buku, sumber dana juga berasal dari orangtua siswa yang membayar diawal tahun. Untuk beberapa kegiatan perpustakaan seperti lomba, biasanya panitia penyelenggara akan membuat proposal dan mencari dana sponsor dari orangtua siswa yang memiliki usaha. Selain itu, panitia juga akan mencari bantuan dana dari yayasan.

c) Alokasi Waktu

Pihak sekolah sudah mengalokasikan waktu khusus sebagai upaya untuk peningkatan literasi siswa. Alokasi waktu yang disediakan terintegrasi 
dalam pembelajaran sekolah disetiap harinya dan/ atau sesuai dengan bulan yang sudah ditentukan. Hal ini guna memperoleh dampak kebijakan yang sesuai dengan tujuan. Jadwal literasi kelas dan diluar kelas termasuk ke dalam program yang terintegrasi dari kurikulum sekolah. kegiatan literasi tersebut berlaku untuk semua kelas dan telah diberikan jadwal untuk setiap harinya. Untuk kegiatan literasi minimal 15 menit.

Agen-agen yang terlibat sangat berkomitmen dengan program yang dibuat. Hal ini juga sejalan dengan hasil penelitian yang dilakukan peneliti di lapangan bahwa seluruh warga turut aktif mengimplementasikan kebijakan tersebut. Mulai dari kepala sekolah, para wakil kepala sekolah, seluruh dewan guru dan orang tua. Dalam menunjang kemampuan manajerial agen pelaksana, pihak sekolah memberikan fasilitas berupa melibatkan guru untuk mengikuti seminar, pelatihan dan atau bimbingan teknis yang diselenggarakan oleh instansi tertentu agar para agen pelaksana kebijakan di sekolah mempunyai kecapakan terkait kebijakan yang sudah ditetapkan. Agar memiliki komitmen yang baik, dalam proses seleksi karyawan dan guru, pihak sekolah membuat tes yang terstandar. Pihak sekolah dalam hal ini kepala sekolah tidak hanya melihat dari latar belakang pendidikan dari si calon saja, tapi juga melihat bagaimana pandangannya terhadap dunia pendidikan, kreativitas, dan tentunya motivasi apa yang menjadikan seorang calon guru atau karyawan untuk menjadi bagian dari SDUA THC. Sehingga diharapkan dapat terjaring guru-guru serta karyawan yang memiliki komitmen bersama untuk mencapai visi misi dan tujuan sekolah.

Garis struktur birokrasi kebijakan terkait literasi sekolah adalah dari pihak manajemen akan menyampaikan program yang diusulkan untuk kemudian disetujui oleh kepala sekolah yang sebelumnya telah melakukan rapat yayasan terlebih dahulu. Program yang sudah disetujui kemudian disosialisasikan kepada pihak-pihak yang terkait agar diberikan arahan program yang akan dilaksanakan. Arahan berupa pelatihan terhadap para dewan guru. Dengan dana yang diminimalisir untuk kegiatan pelatihan tersebut.

Dari paparan di atas maka dapat disimpulkan bahwa untuk mengimplementasikan kebijakan gerakan literasi sekolah, sekolah dasar unggulan Aisyiyah taman harapan Curup telah didukung oleh sumber daya manusia berupa agen-agen yang terlibat untuk mengimplementasikan kebijakan, alokasi dana dari berbagai sumber pemasukkan, dan alokasi waktu untuk mengimplementasikan kebijakan atau program tersebut.

Ditinjau dari kemampuan yang diperoleh siswa setelah diimplementasikannya kebijakan gerakan literasi sekolah adalah kemampuan berbahasa siswa meningkat, kemampun tersebut adalah memaca, menulis, mendengarkan, dan berbicara. Di Sekolah Dasar Unggulan Aisyiyah 
kegiatan literasi dilakukan sangat bervariasi yang menuntut siswa agar tidak hanya dapat membaca dan menulis melainkan memperoleh kemampuan yang lainnya.

Kegiatan literasi di sekolah dasar unggulan Aisyiyah telah terlaksana dengan baik dan memiliki peran dalam meningkatkan minat membaca dan menulis siswa, terlihat dari antusias siswa yang mulai mampu menerapkan kegiatan membaca dan menulis didalam kelas maupun diluar kelas, siswa berpartisipasi aktif dalam kegiatan literasi dengan mendatangi perpustakaan pada jam literasi. Kegiatan literasi juga telah memberikan manfaat bagi siswa seperti, menambah wawasan, lebih memahami bacaan dan materi yang sedang dipelajari, serta siswa mulai menyukai kegiatan untuk menulis.

Secara tidak langsung kegiatan literasi memberi motivasi siswa untuk menyukai kegiatan membaca dan menulis terlihat dari hasil belajar siswa yang meningkat.

\section{Faktor Pendukung dan Penghambat Implementasi Kebijakan Gerakan Literasi Sekolah di Sekolah Dasar Unggulan Aisyiyah Taman Harapan Curup}

3 faktor yang dapat menentukan keberhasilan dan kegagalan implementasi kebijakan, yaitu:

a. Faktor yang terletak pada rumusan kebijakan yang telah dibuat oleh para pengambil keputusan, menyangkut kalimatnya jelas atau tidak, sasarannya tepat atau tidak, mudah dipahami atau tidak, mudah diinterprestasikan atau tidak, dan terlalu sulit dilaksanakan atau tidak. Untuk faktor ini, sekolah telah membuat SOP (Standart Operational Procedure) terkait gerakan literasi sekolah. hal tersebut menjadi upaya sekolah untuk dapat membantu seluruh elemen sekolah dalam memahami program yang telah ditetapkan.

b. Faktor yang terletak pada personil pelaksana, yakni yang menyangkut tingkat pendidikan, pengalaman, motivasi, komitmen, kesetiaan, kinerja, kepercayaan diri, kebiasaan-kebiasaan, serta kemampuan kerjasama dari para pelaku pelaksana kebijakan. Termasuk dalam personil pelaksana adalah latar belakang budaya, bahasa, serta ideologi kepartaian masing-masing. Semua itu akan sangat mempengaruhi cara kerja agen pelaksana secara kolektif dalam menjalankan misi implementasi kebijakan. Terlihat bahwa guru memiliki komitmen yang baik terhadap kebijakan tersebut. hal ini telah disampaikan oleh subjek penelitian terkait sumber daya. Untuk menjadi guru di SDUA THC, sangat memprioritaskan kemampuan, komitmen, dan motivasi belajar yang baik dari guru sehingga hal tersebut dapat membantu berjalannya program tanpa hambatan.

c. Faktor yang terletak pada sistem organisasi pelaksana, yakni menyangkut jaringan sistem, hirarki kewenangan masing-masing peran, model distribusi pekerjaan, gaya kepemimpinan dari pemimpin organisasinya, aturan main organisasi, target masing-masing tahap yang ditetapkan, model monitoring yang biasa dipakai, serta evaluasi yang dipilih. Berkaitan dengan hirarki kewenangan, dalam pelaksanaan kebijakan gerakan literasi sekolah berada ditangan kepala sekolah secara 
langsung. Gaya kepemimpinan dari kepala sekolah SDUA THC adalah terbuka dengan segala masukan.

\section{Simpulan}

1. Implementasi kebijakan gerakan literasi sekolah telah memenuhi syarat implementasi kebijakan yakni berkaitan dengan komunikasi, sumber daya, disposisi dan struktur birokrasi dan sesuai dengan peraturan menteri pendidikan dan kebudayaan. Setelah diimplementasikan kebijakan gerakan literasi sekolah kemampuan berbahasa peserta didik di Sekolah Dasar Unggulan Aisyiyah THC meningkat.

2. Faktor Pendukung Implementasi Kebijakan Gerakan Literasi Sekolah di Sekolah Dasar Unggulan Aisyiyah THC yaitu terdapat sarana dan prasarana, perkembangan media yang sangat membantu, terdapat alokasi waktu dan dana untuk menunjang kecakapan literasi siswa, semua warga sekolah terlibat aktif.

3. Faktor penghambat yaitu kesibukkan masing-masing umi dan ustadz yang menjadikan proses literasi di perpustakaan dan pembuatan mading secara mendadak karena keterbatasan sumber daya manusia. Anak-anak terlihat bosan sebab bukubuku yang menarik sulit didapat.

\section{Referensi:}

Pusat Bahasa Departemen Pendidikan Nasional, Kamus Besar Bahasa Indonesia, (Jakarta: Balai Pustaka), h.263.

${ }^{1}$ Lexy J Moleong, Metodologi Penelitian Kualitatif, (Bandung: Remaja Rosdakarya 2002), h. 3.

${ }^{1}$ Sukarman Syarnubi, Metode Penelitian Kuantitatif dan Kualitatif, (Bengkulu: LP2 STAIN CURUP, 2011), h. 29.

${ }^{1}$ Lexy J. Moleong, Metodologi Penelitian Kualitatif, (Bandung: Remaja Rosda Karya, 2015), h. 6.

Wawancara dengan ibu Enilawati S.Pd.I, wakil kepala sekolah, hari Selasa 8 Mei, pukul 11.30 WIB.

${ }^{1}$ Wawancara dengan ibu Miki Famela S.Pd.I, kepala perpustakaan, pada Selasa hari 8 Mei 2018, pukul 07.30 WIB.

${ }^{1}$ Wawancara dengan ibu Ani Wahyuni S.Pd.I, wali kelas IV, pada hari Selasa 8 Mei 2018, pukul 09.00 WIB.

${ }^{1}$ Wawancara dengan ibu Enilawati S.Pd.I, wakil kepala sekolah, hari Selasa 8 Mei, pukul 11.30 WIB.

${ }^{1}$ Wawancara dengan ibu Miki Famela S.Pd.I, kepala perpustakaan, pada hari Selasa 8 Mei 2018, pukul 07.30 WIB.

${ }^{1}$ Wawancara dengan ibu Enilawati S.Pd.I, wakil kepala sekolah, hari Selasa 8 Mei, pukul 11.30 WIB.

${ }^{1}$ Wawancara dengan ibu Miki Famela S.Pd.I, kepala perpustakaan, pada hari Selasa enin 8 Mei 2018, pukul 07.30 WIB.

${ }^{1}$ Wawancara dengan ibu Ani Wahyuni S.Pd.I, wali kelas IV, pada hari Selasa 8 Mei 2018, pukul 09.00 WIB. 
${ }^{1}$ Wawancara dengan ibu Enilawati S.Pd.I, wakil kepala sekolah, hari Selasa 8 Mei, pukul 11.30 WIB.

Wawancara dengan ibu Miki Famela S.Pd.I, kepala perpustakaan, pada hari Selasa enin 8 Mei 2018, pukul 07.30 WIB.

${ }^{1}$ Wawancara dengan ibu Ani Wahyuni S.Pd.I, wali kelas IV, pada hari Selasa 8 Mei 2018, pukul 09.00 WIB.

${ }^{1}$ Wawancara dengan ibu Enilawati S.Pd.I, wakil kepala sekolah, hari Selasa 8 Mei, pukul 11.30 WIB.

${ }^{1}$ Wawancara dengan ibu Miki Famela S.Pd.I, kepala perpustakaan, pada hari Selasa Senin 8 Mei 2018, pukul 07.30 WIB.

${ }^{1}$ Wawancara dengan ibu Ani Wahyuni S.Pd.I, wali kelas IV, pada hari Selasa 8 Mei 2018, pukul 09.00 WIB.

1 Wawancara dengan ibu Enilawati S.Pd.I, wakil kepala sekolah, hari Selasa 8 Mei, pukul 11.30 WIB.

${ }^{1}$ Wawancara dengan ibu Ani Wahyuni S.Pd.I, wali kelas IV, pada hari Selasa 8 Mei 2018, pukul 09.00 WIB.

${ }^{1}$ Wawancara dengan ibu Miki Famela S.Pd.I, kepala perpustakaan, pada hari Selasa 8 Mei 2018, pukul 07.30 WIB.

${ }^{1}$ Wawancara dengan ibu Miki Famela S.Pd.I, kepala perpustakaan, pada hari Selasa Senin 8 Mei 2018, pukul 07.30 WIB.

${ }^{1}$ Wawancara dengan ibu Ani Wahyuni S.Pd.I, wali kelas IV, pada hari Selasa 8 Mei 2018, pukul 09.00 WIB.

1 Wawancara dengan ibu Enilawati S.Pd.I, wakil kepala sekolah, hari Selasa 8 Mei, pukul 11.30 WIB.

${ }^{1}$ Wawancara dengan ibu Ani Wahyuni S.Pd.I, wali kelas IV, pada hari Selasa 8 Mei 2018, pukul 09.00 WIB.

${ }^{1}$ Wawancara dengan ibu Miki Famela S.Pd.I, kepala perpustakaan, pada hari Selasa 8 Mei 2018, pukul 07.30 WIB.

Wawancara dengan ibu Enilawati S.Pd.I, wakil kepala sekolah, hari Selasa 8 Mei, pukul 11.30 WIB.

${ }^{1}$ Wawancara dengan ibu Miki Famela S.Pd.I, kepala perpustakaan, pada hari Selasa 8 Mei 2018, pukul 07.30 WIB.

${ }^{1}$ Wawancara dengan ibu Enilawati S.Pd.I, wakil kepala sekolah, hari Selasa 8 Mei, pukul 11.30 WIB.

${ }^{1}$ Wawancara dengan ibu Miki Famela S.Pd.I, kepala perpustakaan, pada hari Selasa 8 Mei 2018, pukul 07.30 WIB.

${ }^{1}$ Wawancara dengan ibu Ani Wahyuni S.Pd.I, wali kelas IV, pada hari Selasa 8 Mei 2018, pukul 09.00 WIB.

Wawancara dengan ibu Enilawati S.Pd.I, wakil kepala sekolah, hari Selasa 8 Mei, pukul 11.30 WIB.

${ }^{1}$ Wawancara dengan ibu Miki Famela S.Pd.I, kepala perpustakaan, pada hari Selasa 8 Mei 2018, pukul 07.30 WIB.

${ }^{1}$ Wawancara dengan ibu Ani Wahyuni S.Pd.I, wali kelas IV, pada hari Selasa 8 Mei 2018, pukul 09.00 WIB.

${ }^{1}$ Wawancara dengan ibu Enilawati S.Pd.I, wakil kepala sekolah, hari Selasa 8 Mei, pukul 11.30 WIB 
${ }^{1}$ Wawancara dengan ibu Miki Famela S.Pd.I, kepala perpustakaan, pada hari Selasa 8 Mei 2018, pukul 07.30 WIB.

${ }^{1}$ Wawancara dengan ibu Ani Wahyuni S.Pd.I, wali kelas IV, pada hari Selasa 8 Mei 2018, pukul 09.00 WIB.

${ }^{1}$ Wawancara dengan ibu Miki Famela S.Pd.I, kepala perpustakaan, pada hari Selasa 8 Mei 2018, pukul 07.30 WIB.

${ }^{1}$ Wawancara dengan ibu Ani Wahyuni S.Pd.I, wali kelas IV, pada hari Selasa 8 Mei 2018, pukul 09.00 WIB.

${ }^{1}$ Kamus Besar Bahasa Indonesia, (Jakarta: Balai Pustaka, 2010), h. 28

${ }^{1}$ https://pengertiandefinisi.com/pengertian-analisa-menurut-ahli/, 20 Agustus 2017

${ }^{1}$ Dewi Utama Faizah, et all, Panduan Gerakan Literasi di Sekolah Dasar, (Jakarta: Direktorat Jenderal Pendidikan Dasar dan Menengah Kementerian Pendidikan dan Kebudayaan, 2016), h. 2

${ }^{1}$ Pangesti Wiedarti, at all, Op. Cit., h. 7

${ }^{1}$ Laila Zumrotin, 2017, "Skripsi: Analisis penerapan Gerakan Literasi Sekolah (Kegiatan Membaca) dalam meningkatkan keterampilan membaca siswa di SD Unggulan Aisyiyah Taman Harapan Curup, IAIN Rejang Lebong, h. 86

Maryaai, Kun dan Juju Suryawati. 2007. Sosiologi untuk SMA dan MA Kelas XII. Jakarta: Esis.

Arikunto, Suharsimi, 2002.

Prosedur Penelitian; Suatu Pendekatan Praktek.

Jakarta:Renika Cipta.Sugiono, 2010.

Metode Penelitian Kuantitatif Kualitatif dan $R \& D$.

Bandung:Alfabeta 
Estetik, Vol.2 No.2, November2019

ISSN 2622-1810 (p) 2622-1829 (e) 